\title{
Kinetics and mechanism of heterogeneous oxidation of sulfur dioxide by ozone on surface of calcium carbonate
}

\author{
L. Li, Z. M. Chen, Y. H. Zhang, T. Zhu, J. L. Li, and J. Ding \\ State Key Joint Laboratory of Environment Simulation and Pollution Control, College of Environmental Sciences, Peking \\ University, Beijing 100871, China
}

Received: 18 October 2005 - Published in Atmos. Chem. Phys. Discuss.: 17 January 2006

Revised: 19 April 2006 - Accepted: 8 May 2006 - Published: 29 June 2006

\begin{abstract}
Sulfate particles play a key role in the air quality and the global climate, but the heterogeneous formation mechanism of sulfates on surfaces of atmospheric particles is not well established. Carbonates, which act as a reactive component in mineral dust due to their special chemical properties, may contribute significantly to the sulfate formation by heterogeneous processes. This paper presents a study on the oxidation of $\mathrm{SO}_{2}$ by $\mathrm{O}_{3}$ on $\mathrm{CaCO}_{3}$ particles. Using Diffuse Reflectance Infrared Fourier Transform Spectroscopy (DRIFTS), the formation of sulfite and sulfate on the surface was identified, and the roles of $\mathrm{O}_{3}$ and water in oxidation processes were determined. The results showed that in the presence of $\mathrm{O}_{3}, \mathrm{SO}_{2}$ can be oxidized to sulfate on the surface of $\mathrm{CaCO}_{3}$ particles. The reaction is first order in $\mathrm{SO}_{2}$ and zero order in $\mathrm{O}_{3}$. The reactive uptake coefficient for $\mathrm{SO}_{2}\left[(0.6-9.8) \times 10^{14}\right.$ molecule $\left.\mathrm{cm}^{-3}\right]$ oxidation by $\mathrm{O}_{3}\left[(1.2-12) \times 10^{14}\right.$ molecule $\left.\mathrm{cm}^{-3}\right]$ was determined to be $(1.4 \pm 0.3) \times 10^{-7}$ using the BET area as the reactive area and $(7.7 \pm 1.6) \times 10^{-4}$ using the geometric area. A twostage mechanism that involves adsorption of $\mathrm{SO}_{2}$ followed by $\mathrm{O}_{3}$ oxidation is proposed and the adsorption of $\mathrm{SO}_{2}$ on the $\mathrm{CaCO}_{3}$ surface is the rate-determining step. The proposed mechanism can well explain the experiment results. The atmospheric implications were explored based on a box model calculation. It was found that the heterogeneous reaction might be an important pathway for sulfate formation in the atmosphere.
\end{abstract}

\section{Introduction}

Particulate matter (PM) plays an important role in the atmospheric environment as well as in climate change (Dentener et al., 1996; Jacob, 2000). It provides reactive

Correspondence to: Y. H. Zhang

(yhzhang@pku.edu.cn) sites for heterogeneous reactions, and also serves as a long range transporting carrier for many condensed and adsorbed species, thus influences atmospheric chemistry and climate directly and indirectly (Ravishankara, 1997; Ravishankara and Longfellow, 1999). Mineral dust is an important component of PM with an estimated annual contribution of 1000$3000 \mathrm{Tg}$ of solids to the atmosphere. It consists mainly of quartz, feldspars, carbonates (calcite, dolomite) and clays (illite, kaolinite, chlorite, montmorillonite/smectite) (Dentener et al., 1996; Li et al., 1996; Hanisch and Crowley, 2001). Mineral dust can be easily elevated to high altitudes and then be transported over a long distance, during which these particles have opportunities to interact with trace gases (Seinfeld and Pandis, 1998; Phadnis and Carmichael, 2000; Goudie and Middleton, 2001; Xiao et al., 1997). Carbonates act as a reactive component on mineral aerosols in the troposphere (Usher et al., 2003; Song and Carmichael, 2001), in addition to their significance to the global $\mathrm{CO}_{2}$ exchange and energy storage (Robbins and Fabry, 1994; Sundquist, 1985). Among several carbonates, calcite has been identified as an important constituent in the mineral dust (Putnis, 1992), for example, it makes up 3.5\%-36.5\% of PM10 in some Chinese cities (Lu and Shao, 2003; Davis and Guo, 2000).

Field measurements showed that the surface of mineral dust was usually coated with sulfate (Mamane et al., 1980; Savoie et al., 1989; Zhuang et al., 1999; Zhang et al., 2000; Zhu et al., 2003) and there is a correlation between non-seasalt sulfate and mineral aerosols (Carmichael et al., 1996; Nishikawa et al., 1991; Zhang et al., 2000). It is well known that sulfate particles play a key role in the global climate by participating as cloud condensation nuclei and scattering solar radiation, thereby having a cooling effect on the atmosphere (Dentener et al., 1996; Charlson et al., 1990; Seinfeld and Pandis, 1998). $\mathrm{SO}_{2}$ can be oxidized to sulfate in several chemical processes, including gaseous oxidation by $\mathrm{OH}$ radicals (Seinfeld and Pandis, 1998), aqueous oxidation by oxygen which is catalyzed by iron-containing species (Faust

Published by Copernicus GmbH on behalf of the European Geosciences Union. 
et al., 1989; Martin and Good, 1991; Siefert et al., 1996), aqueous oxidation by ozone and hydrogen peroxide (Keene et al., 1998; Capaldo et al., 1999; Krischke et al., 2000; Zuo et al., 1993; Chandler et al., 1988; Rattigan et al., 2000; Hoppel and Caffrey, 2001), and possible heterogeneous oxidation on particle surfaces. There is little knowledge about heterogeneous oxidations of $\mathrm{SO}_{2}$, e.g., the mechanisms of sulfate formation on mineral dusts are not completely elucidated (Dentener et al., 1996). Recently, a number of different substrates such as Saharan dust (Ullerstam et al., 2002, 2003), some metal oxides (Goodman et al., 2001; Usher et al., 2002), and China loess (Usher et al., 2002) were used to study the kinetics of heterogeneous $\mathrm{SO}_{2}$ oxidation on these types of particles. The reactive uptake coefficients for $\mathrm{SO}_{2}$ oxidation by $\mathrm{O}_{3}$ on Saharan dust was studied (Ullerstam et al., 2002, 2003). It has been proposed that the uptake coefficient of China loess can be predicted from the reactivity of its single components along with the average composition of the loess (Usher et al., 2002). However, these studies did not explore such questions as: which components in the mineral dust are important and what are the reaction mechanisms? Al-Hosney et al. (2004) found from spectral measurements by FTIR that carbonic acid was an important intermediate on the surface of $\mathrm{CaCO}_{3}$, but the dynamic processes and mechanisms of the heterogeneous chemistry of $\mathrm{SO}_{2}$ on the surface of $\mathrm{CaCO}_{3}$ are still not fully explored.

The objectives of this paper are to investigate the kinetics and mechanism of $\mathrm{SO}_{2}$ oxidation by $\mathrm{O}_{3}$ on the surface of $\mathrm{CaCO}_{3}$ using the Diffuse Reflectance Infrared Fourier Transform Spectroscopy (DRIFTS) technique, and to evaluate the atmospheric implication based on a box model calculation.

\section{Experimental}

There are several methods for the observation of the interaction between the gas-phase and solid surface, such as Knudsen cells and flow tube reactors. The DRIFTS has been employed to probe the heterogeneous chemistry on particle surfaces (Vogt et al., 1994; Finlayson-Pitts, 2000). The advantage of DRIFTS is that it can be used to measure in situ spectra of the reaction products without interrupting the reaction processes (Finlayson-Pitts, 2000). In this paper, DRIFTS was used to probe the $\mathrm{SO}_{2}$ oxidation by $\mathrm{O}_{3}$ on $\mathrm{CaCO}_{3}$ particles.

A Nicolet Nexus FTIR Spectrometer equipped with a mercury cadmium telluride (MCT) detector and DRIFTS optics (Model DRA-2CO, Harrick Scientific corp.) was used to record in situ infrared spectra, ranging from 4000 to $600 \mathrm{~cm}^{-1}$. The spectra were recorded at a resolution of $4 \mathrm{~cm}^{-1}$, and 128 scans were usually averaged for each spectrum corresponding to a time resolution of $2 \mathrm{~min}$. To improve the time resolution for experiments in which the initial uptake coefficients were determined, only 32 scans were averaged resulting in a time resolution of $40 \mathrm{~s}$. The temperature of the sample holder was controlled by a regulator associated with a thermocouple mounted directly underneath the sample holder. The probing depth of IR beam is less than $0.2 \mathrm{~mm}$ of powder layers in the reactor. Only the uppermost few layers of samples were explored.

Calcium carbonate powder was purchased from commercial sources (Alfa Aesar). $\mathrm{CaCO}_{3}$ samples were ground to a diameter distribution of around $6 \mu \mathrm{m}$ and then were kept in a desiccator, assuring that the same powder sample was used in all experiments. The powder surface area was measured with a ASAP2010 BET apparatus that used a multipoint Brunauer-Emmett-Teller (BET) analysis. The BET area was determined as $1.95 \mathrm{~m}^{2} \mathrm{~g}^{-1}$.

The gas supply system was composed of four inlet lines. The first line supplied diluted $\mathrm{SO}_{2}$ mixed with $\mathrm{N}_{2}$; the second line was used to provide ozone, which was prepared by an ozone generator which irradiated pure oxygen by UV lamps, resulting in a mixture of ozone and oxygen; the third line supplied water vapor mixed in nitrogen gas and the fourth line was used to provide additional nitrogen gas for dilution. All gases were mixed together before entering the reactor (Model HVC-DR3, Harrick Scientific Corp.) (Fig. 1), resulting in a total flow of $400 \mathrm{sccm}$ flow of synthetic air (20\% oxygen and $80 \%$ nitrogen) with additions of $\mathrm{SO}_{2}, \mathrm{O}_{3}$ and $\mathrm{H}_{2} \mathrm{O}$. The reactive gas flow was forced through the powder.

The reactor was flushed with nitrogen at room temperature before an experiment began. A background spectrum of the unreacted sample in the reactor was recorded before the reactive gas was introduced. All spectra were collected on this background. Sythetic air mixtures with specific concentrations of $\mathrm{SO}_{2}$, or of $\mathrm{SO}_{2}$ and $\mathrm{O}_{3}$ were then introduced as reactant gases.

A typical experiment lasted $180 \mathrm{~min}$; spectra were collected at two-minute intervals during the initial $20 \mathrm{~min}$ of the experiment. Subsequently, the spectra were collected every 10 or 20 min depending upon the concentration of the reactants in the experiment.

\section{Results and discussion}

In order to explore the mechanisms of $\mathrm{SO}_{2}$ surface oxidation by $\mathrm{O}_{3}$, the following aspects must be investigated. First, the sequence of reaction steps must be identified. Second, the kinetics parameters, for example, uptake coefficients, must be determined. From these two pieces of information the final mechanism is deduced.

\subsection{Step-exposure of $\mathrm{SO}_{2}$ and $\mathrm{O}_{3}$}

A step-exposure experiment was designed in this study to probe the detail of the $\mathrm{SO}_{2}$ surface oxidation by $\mathrm{O}_{3}$. The experiment includes two steps, namely the sequential exposure to $\mathrm{SO}_{2}$ and $\mathrm{O}_{3}$. When $\mathrm{SO}_{2}$ alone was introduced to the flow system with $40 \% R H$ in synthetic air, an infrared 


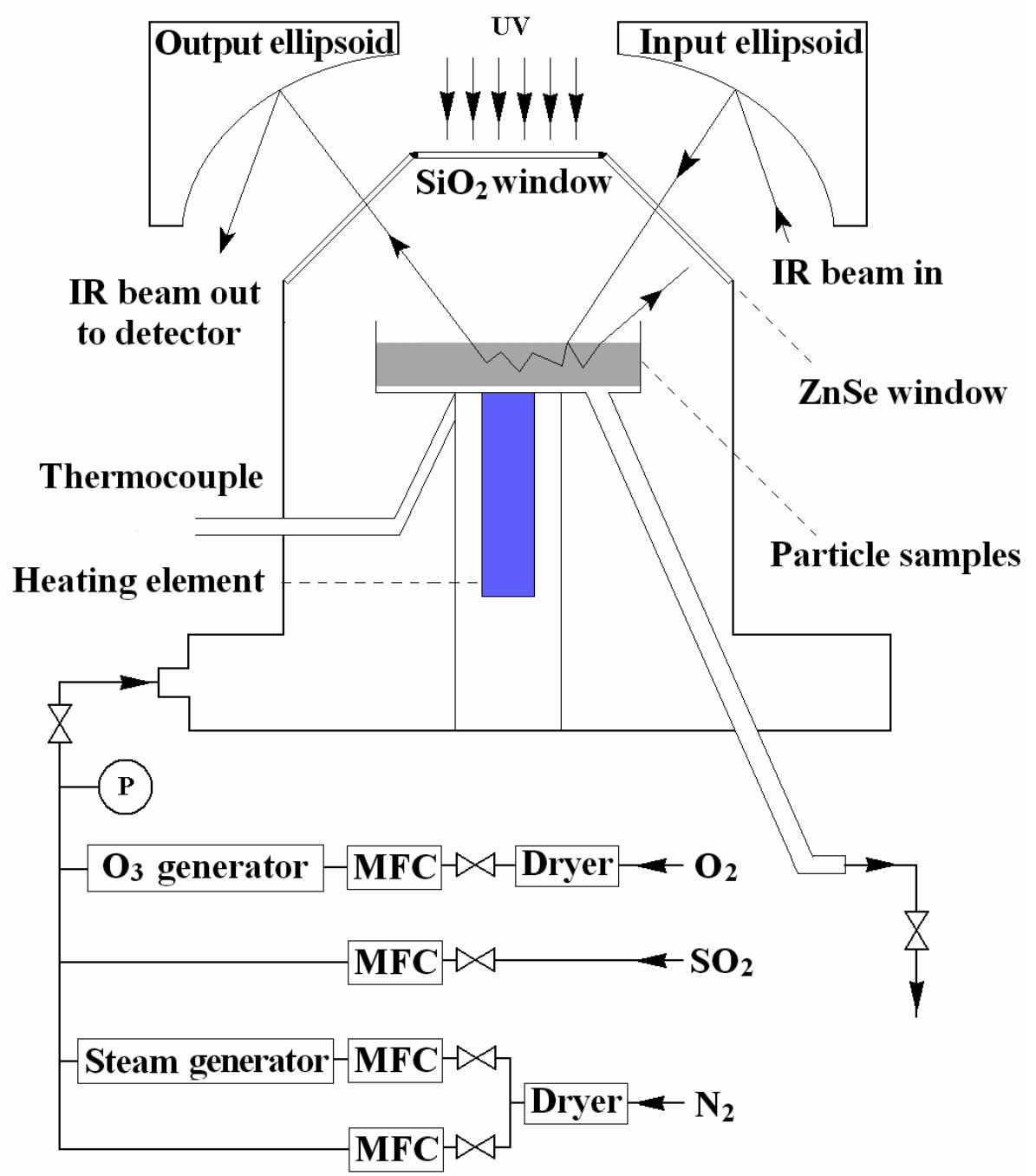

Fig. 1. Schematic diagram of the experimental set-up including the DRIFTS apparatus, the $\mathrm{O}_{3}$ generator, steam generator, pressure gauge (P), mass flow controller (MFC), silicon and zeolite dryer, cold trap, pump and mixing lines.

band at $1000-900 \mathrm{~cm}^{-1}$ was observed (Fig. 2b, inset) which corresponds to the stretching vibration $\left(v_{3}\right)$ of the sulfite (Nakamoto, 1997). This band cannot be seen when $\mathrm{CaCO}_{3}$ was exposed to $\mathrm{SO}_{2}$ under dry air. After the $\mathrm{SO}_{2}$ adsorption was saturated and the integrated absorbance of the band did not increase after $60 \mathrm{~min}$, the $\mathrm{SO}_{2}$ flow was stopped and $\mathrm{O}_{3}$ was introduced to the reaction system. The band at $980 \mathrm{~cm}^{-1}$ disappeared in a few minutes and another band at $1130 \mathrm{~cm}^{-1}$ appeared (Fig. 2c, inset), that corresponds to the stretching vibration $\left(v_{3}\right)$ of sulfate (Nakamoto, 1997). After ten minutes, the band did not increase (Fig. 2d, inset). The time needed for the sulfite oxidation by $\mathrm{O}_{3}$ is much shorter than that for the $\mathrm{SO}_{2}$ adsorption saturation. Figure 2 illustrates the evolution of the integrated absorbance of the sulfite band and sulfate band during the experiment. This experimental result demonstrates that $\mathrm{SO}_{2}$ can be absorbed on the surface of $\mathrm{CaCO}_{3}$ to form sulfite that can be oxidized into sulfate by
$\mathrm{O}_{3}$. This indicates that the adsorption of $\mathrm{SO}_{2}$ on the surface of $\mathrm{CaCO}_{3}$ is relatively slow, but, the sulfite oxidation by $\mathrm{O}_{3}$ is rapid.

In an additional experiment, the $\mathrm{CaCO}_{3}$ particle layers were exposed to a gas mixture of $\mathrm{O}_{3}$ in synthetic air (without $\mathrm{SO} 2$ addition) to study the interaction between $\mathrm{O}_{3}$ and $\mathrm{CaCO}_{3}$. No obvious $\mathrm{O}_{3}$ absorption bands occurred. The $\mathrm{O}_{3}$ absorption bands were weak and overlapped with the sulfate absorption bands. But the Knudsen Cell experiments indicated that $\mathrm{O}_{3}$ adsorption on $\mathrm{CaCO}_{3}$ exists (Alebić-Juretić et al., 2000; Usher et al., 2002). When $\mathrm{CaCO}_{3}$ surface after pretreatment with $\mathrm{O}_{3}$ was exposed to $\mathrm{SO}_{2}$, only the bands of sulfite could be observed, and no bands of sulfate could be found. This experimental result indicates that $\mathrm{O}_{3}$ just undergoes reversible adsorption in absence of a reactant.

To further prove the effects of $\mathrm{O}_{3}$ oxidation, an external mixture of $\mathrm{CaSO}_{3}$ and $\mathrm{CaCO}_{3}$ (with a sulfite concentration 


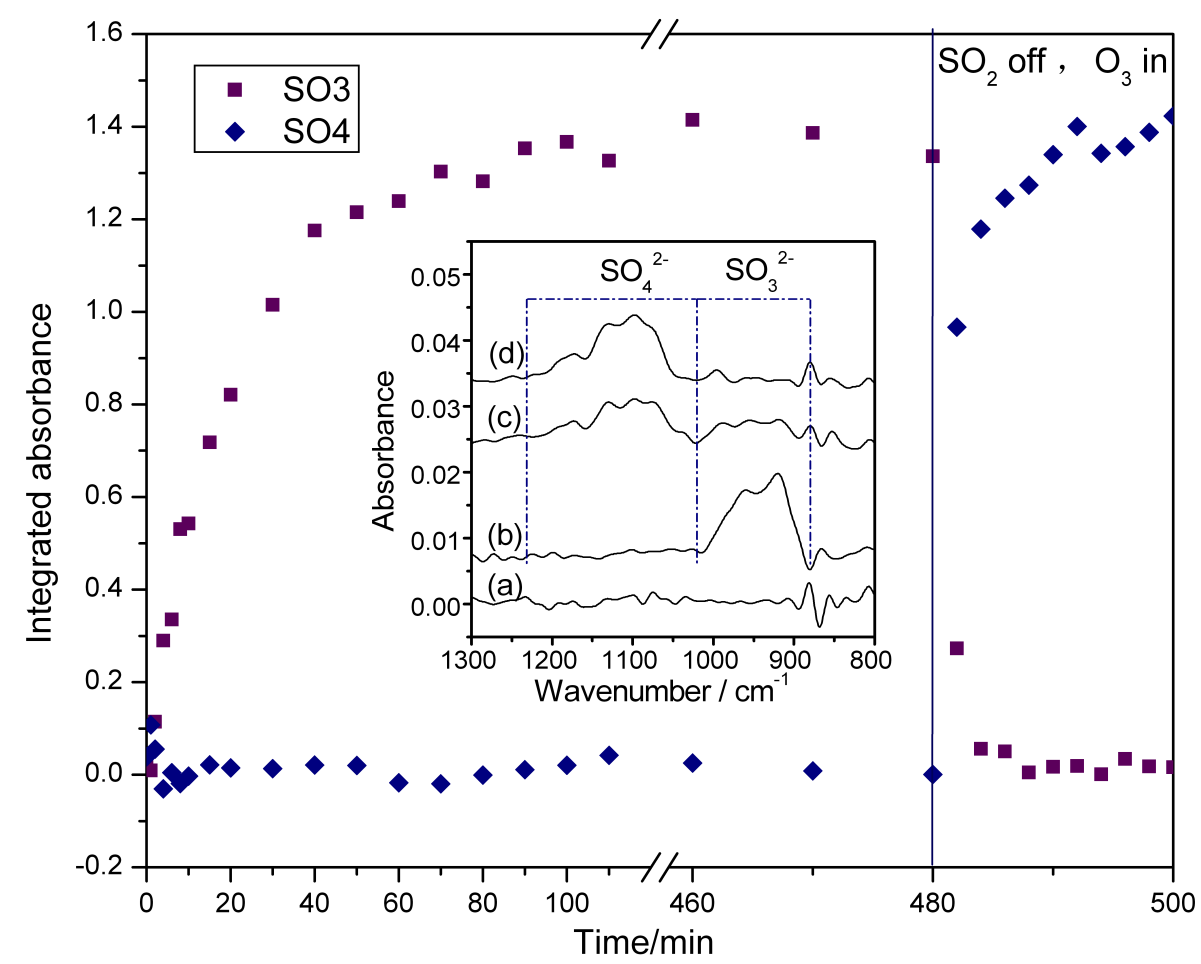

Fig. 2. Integrated absorbance of the DRIFTS band of sulfate and sulfite on $\mathrm{CaCO}_{3}$ in the step-exposure experiment. The inset shows the in situ DRIFTS spectra recorded during the step-exposure experiment $\mathrm{SO}_{2}$ and $\mathrm{O}_{3}$ respectively. Product spectra (a) before addition of $\mathrm{SO}_{2}$, (b) the adsorption rate becomes stable after addition of $\mathrm{SO}_{2}$, (c) after cutting off $\mathrm{SO}_{2}$ supply and the addition of $\mathrm{O}_{3}$ for 4 min, (d) 30 min after the addition of $\mathrm{O}_{3}$. Spectra are shifted by $+0.01,+0.025$ and +0.035 absorption units, for (b), (c) and (d), respectively.

of about $15 \%$ by weight) was exposed to $\mathrm{O}_{3}(20 \mathrm{ppm})$ at $40 \%$ $R H$. The unexposed sample was used to collect the background spectrum. The sulfate positive band at $1100 \mathrm{~cm}^{-1}$ and the sulfite negative band at $1000 \mathrm{~cm}^{-1}$ were observed in the subsequent reaction (Fig. 3), this phenomenon suggests that sulfite can be easily oxidized to sulfate by $\mathrm{O}_{3}$.

\subsection{Simultaneous exposure of $\mathrm{SO}_{2}$ and $\mathrm{O}_{3}$}

$\mathrm{CaCO}_{3}$ particle layers were exposed simultaneously to $\mathrm{SO}_{2}$ $(20 \mathrm{ppm})$ and $\mathrm{O}_{3}(20 \mathrm{ppm})$, the main products detected by DRIFTS and ion chromatographic (IC) analysis were sulfate. Little sulfite was observed in the DRIFTS and IC experiments. The stretching vibration of sulfate $\left(\nu_{3}\right)$ at $1130 \mathrm{~cm}^{-1}$ on $\mathrm{CaCO}_{3}$ in our experiment is somewhat different from that with $1240 \mathrm{~cm}^{-1}$ on mineral dust (Ullerstam et al., 2002). Figure 4 presents a time series of adsorption spectra recorded during the reaction of $\mathrm{SO}_{2}$ and $\mathrm{O}_{3}$ on $\mathrm{CaCO}_{3}$.

After a typical experiment, the sample was further treated in several ways. Figure 5a is a spectrum of a particle sample when the experiment was finished. First, the reactor containing the sample was evacuated to $10 \mathrm{~Pa}$ and a spectrum was recorded (Fig. 5b) which changed little from before evacuation. Second, the sample was heated to $300^{\circ} \mathrm{C}$ under a vacuum and another spectrum was recorded when the sample was cooled to room temperature (Fig. 5c). The spectrum in Fig. $5 d$ is the residue from subtraction of the spectrum (5a) from $(5 \mathrm{c})$. From Fig. $5 \mathrm{~d}$, it can be seen that the peaks at 1091 and $1007 \mathrm{~cm}^{-1}$ are shortened, while the peaks at 1198 , 1137 and $1112 \mathrm{~cm}^{-1}$ are increased. This is caused partly by adsorbed water that would be desorbed from particle surfaces when the reactor was evacuated and heated. Although the shape of the sulfate absorption bands changed obviously, the total integrated absorbance of the sulfate bands remained constant. This suggests that the total amount of sulfate is unchanged if the absorption coefficients for different chemical forms of sulfate are assumed to be the same. This result indicates that under the conditions of vacuum and heating, the sulfate would not be desorbed from the surface of $\mathrm{CaCO}_{3}$.

In order to further analyze the region from 1300 to $950 \mathrm{~cm}^{-1}$, a curve-fitting procedure was used to separate overlapping sulfate bands (Börensen et al., 2000). Lorenz and Gaussian functions were used to fit five bands (asymmetric stretching vibrations) which possibly represent several different chemical forms of sulfate (Fig. 6a). The temporal behaviour of the five bands was then analyzed to study their possibly different kinetics behaviour. An example is plotted in Fig. 6b, showing the fitted bands as a function of reaction time. As seen from this figure, all of the bands grew at similar rates and showed similar trend changes with 


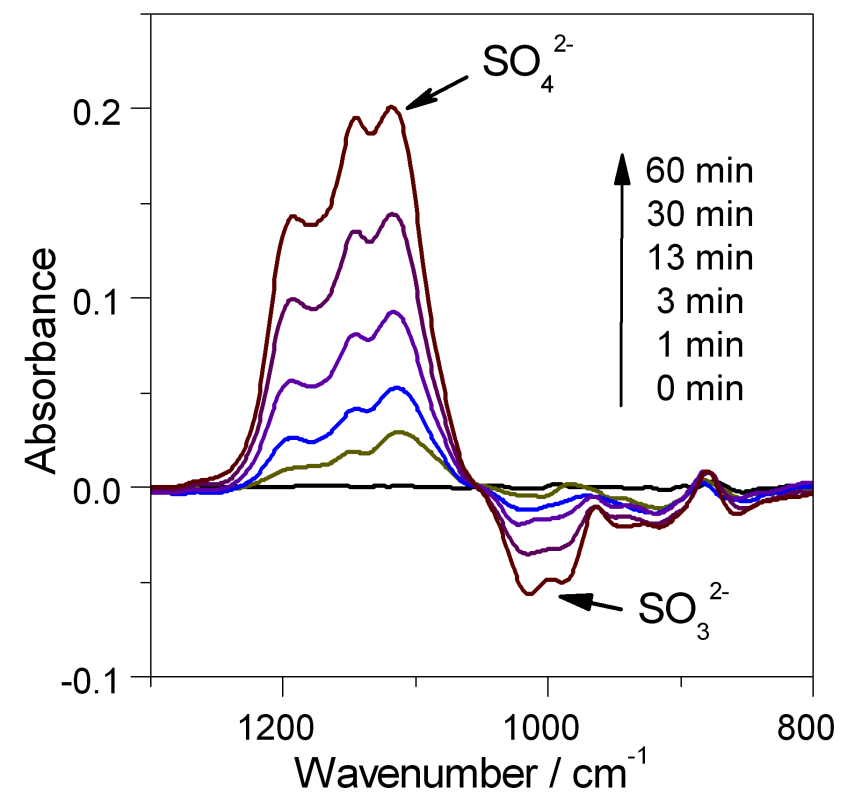

Fig. 3. In situ DRIFTS spectra of $\mathrm{O}_{3}$ oxidation of sulfite mixed into $\mathrm{CaCO}_{3}$ powder. The unexposed sample was used to collect a background spectrum and the sulfate positive band at $1100 \mathrm{~cm}^{-1}$ and the sulfite negative band at $1000 \mathrm{~cm}^{-1}$ changed with the reaction time.

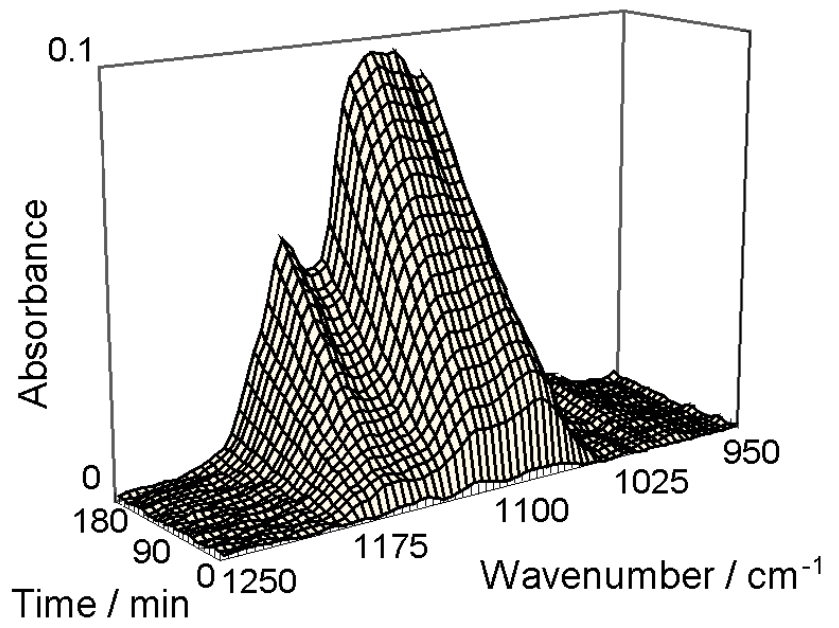

Fig. 4. Absorption bands observed during the reaction of $\mathrm{SO}_{2}$ with $\mathrm{O}_{3}$ on the surface of $\mathrm{CaCO}_{3}$ as a function of reaction time $\left(\left[\mathrm{SO}_{2}\right]=4.92 \times 10^{14}\right.$ molecules $\mathrm{cm}^{-3}$, $\left[\mathrm{O}_{3}\right]=4.92 \times 10^{14}$ molecules $\left.\mathrm{cm}^{-3}\right)$.

reaction time. All of the five bands grew fast at the beginning of the reaction, then slowed as the reaction proceeded and finally became stable after $60 \mathrm{~min}$. This indicates that the total integrated absorbance of the overlapping bands can be used to derive the formation rate of sulfate, thus the individual bands need not be separated to analyze the kinetics of the heterogeneous prosess.

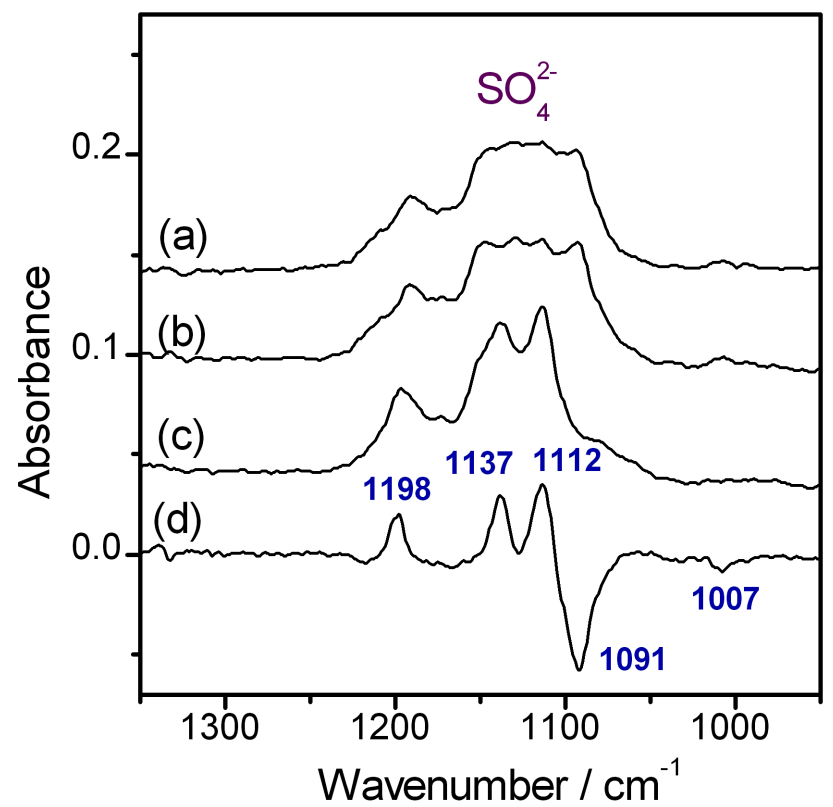

Fig. 5. Spectra of sulfate when the reactor with the sample was evacuated and heated. (a) Sample after a typical experiment with $\mathrm{SO}_{2}$ and $\mathrm{O}_{3}$ exposure, follwed by evacuation to $10 \mathrm{~Pa}(\mathbf{b})$ and, further heating to $300^{\circ} \mathrm{C}$ (c); (d) difference between the spectrum (a) and (c).
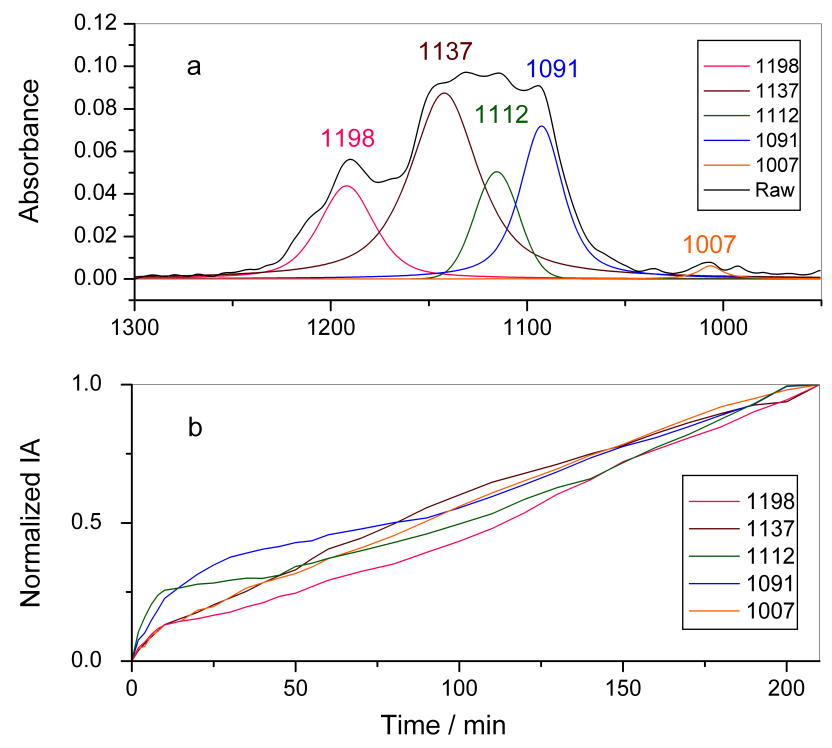

Fig. 6. Deconvolution of overlapping bands using Lorenz and Gaussian curves. (a) An absorption spectrum recorded in the reaction of $\mathrm{SO}_{2}$ and $\mathrm{O}_{3}$ with calcium carbonate. Five bands were fitted to the band of sulfate according to the subtractive spectrum seen in Fig. 5d. (b) The normalized integrated absorbances of all the five bands as a function of reaction time were plotted. All the five bands grew at the similar rates and showed similar trends with reaction time. 
Table 1. Experimental concentrations and reactive uptake coefficient for $\mathrm{SO}_{2}$ for the reaction of $\mathrm{SO}_{2}$ and $\mathrm{O}_{3}$ on $\mathrm{CaCO}_{3}$ at $20^{\circ} \mathrm{C}$ with RH $=40 \%$.

\begin{tabular}{|c|c|c|c|c|c|c|}
\hline $\begin{array}{c}{\left[\mathrm{SO}_{2}\right]} \\
\left(10^{14} \text { molecule } \mathrm{cm}^{-3}\right)\end{array}$ & $\begin{array}{c}{\left[\mathrm{O}_{3}\right]} \\
\left(10^{14} \text { molecule } \mathrm{cm}^{-3}\right)\end{array}$ & $\begin{array}{c}R H \\
\%\end{array}$ & $\begin{array}{c}\gamma_{\mathrm{SO} 2} \\
\text { (Geometric) } \\
10^{-5}\end{array}$ & $\begin{array}{c}\gamma_{\mathrm{SO} 2} \\
(\mathrm{BET}) \\
10^{-8}\end{array}$ & $\begin{array}{c}\gamma_{\mathrm{O} 3} \\
\text { (Geometric) } \\
10^{-4}\end{array}$ & $\begin{array}{c}\gamma_{\mathrm{O} 3} \\
(\mathrm{BET}) \\
10^{-8}\end{array}$ \\
\hline $0.6-9.8$ & 4.9 & 40 & $\begin{array}{c}77 \pm 16\left(\gamma_{0}\right) \\
8.1 \pm 2.6\left(\gamma_{s s}\right)\end{array}$ & $\begin{array}{c}14 \pm 3\left(\gamma_{0}\right) \\
1.5 \pm 0.5\left(\gamma_{s s}\right)\end{array}$ & & \\
\hline 4.9 & $1.2-12$ & 40 & & & $\begin{array}{c}30-3\left(\gamma_{0}\right) \\
1.5-0.4\left(\gamma_{s s}\right)\end{array}$ & $\begin{array}{c}54-5\left(\gamma_{0}\right) \\
2.6-0.6\left(\gamma_{s s}\right)\end{array}$ \\
\hline 4.9 & 4.9 & $5-60$ & $\begin{array}{c}80 \pm 5\left(\gamma_{0}\right) \\
1.0-10.7\left(\gamma_{s s}\right)\end{array}$ & $\begin{array}{c}14 \pm 2\left(\gamma_{0}\right) \\
0.2-2.0\left(\gamma_{s s}\right)\end{array}$ & $\begin{array}{l}6.9 \pm 0.4\left(\gamma_{0}\right) \\
9.2-0.9\left(\gamma_{s s}\right)\end{array}$ & $\begin{array}{c}12 \pm 1\left(\gamma_{0}\right) \\
1.8-0.2\left(\gamma_{s s}\right)\end{array}$ \\
\hline
\end{tabular}

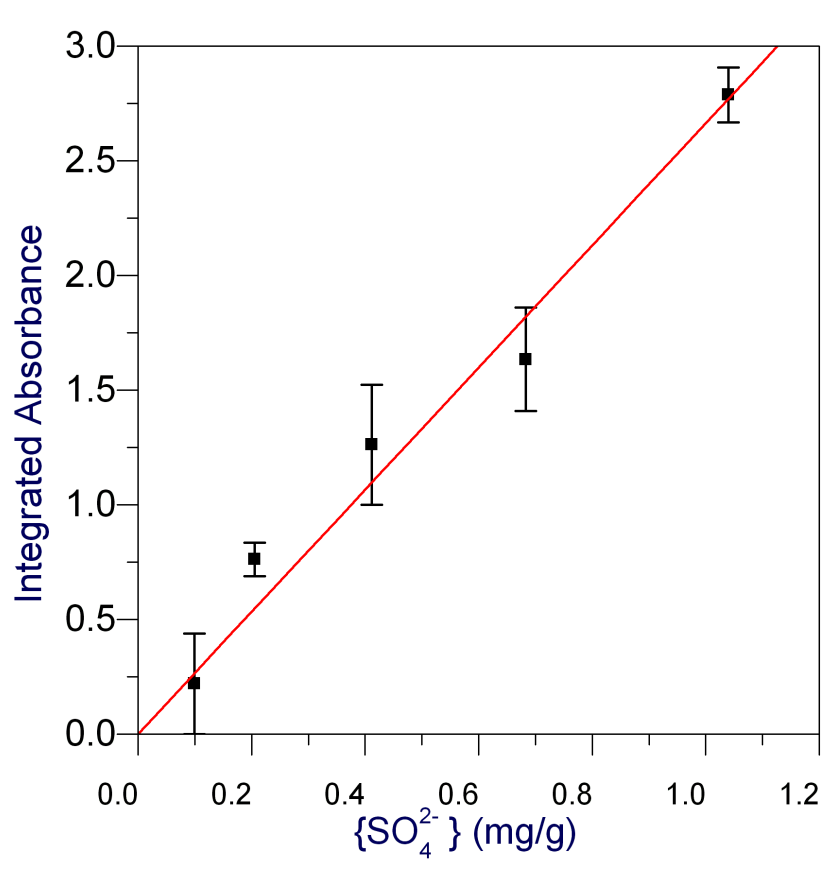

Fig. 7. Calibration curve for the integrated absorbance versus the concentration of sulfate.

\subsection{Reaction kinetics}

The amount of sulfate on the particulate sample was determined in order to quantify the sulfate formation rate $\mathrm{d}\left\{\mathrm{SO}_{4}^{2-}\right\} / \mathrm{dt}$ in terms of the reactive uptake coefficient. The reactive uptake coefficient, $\gamma$, is defined as the rate of product formation $\left(\mathrm{d}\left\{\mathrm{SO}_{4}^{2-}\right\} / \mathrm{dt}\right)$ divided by the rate of surface collisions per unit time $(\mathrm{Z})$.

$\gamma=\frac{d\left\{\mathrm{SO}_{4}^{2-}\right\} / d t}{Z}$

$Z=\frac{1}{4} \bar{c} A_{\text {surface }}\left[\mathrm{SO}_{2}\right]$ $\bar{c}=\sqrt{\frac{8 R T}{\pi M_{\mathrm{SO}_{2}}}}$

where $\mathrm{Z}$ is the rate of collisions between $\mathrm{SO}_{2}$ and particles, $\bar{c}$ is the mean molecular velocity of $\mathrm{SO}_{2}, \mathrm{~A}_{\text {surface }}$ is the effective sample surface, $\mathrm{R}$ is the gas constant, $\mathrm{T}$ is the temperature and $\mathrm{M}_{\mathrm{SO} 2}$ is the molecular weight of $\mathrm{SO}_{2}$. Concentrations marked with \{\} indicate surface species, whereas [ ] indicate the concentration of gas-phase species. Two extreme cases of effective sample surface were considered for calculating the uptake coefficient. If the reaction probability is high, the reactants would have no time to diffuse into the sample before reacting and the effective surface area will be the geometric surface area of the sample. If the reaction probability is low, the reactants may have enough time for diffusion into the entire sample and thus the BET surface area would more appropriately represent the effective area. If sulfate formed is evenly distributed into the sample, the effective surface area might approach the BET surface area.

The amount of sulfate ions formed during the reaction was determined by the DRIFTS calibration curves made by mixing the weighted pure $\mathrm{CaSO}_{4}$ in $\mathrm{CaCO}_{3}$ to a certain concentration. The sulfate formation rate was translated from $\mathrm{ABU}$ $\mathrm{s}^{-1}$ to $\mathrm{SO}_{4}^{2-} \mathrm{s}^{-1}$ by the calibration curve (Fig. 7).

Two stages were considered for the kinetic study. As soon as the reactive gas was introduced into the particle layers, the IR bands increased quickly, and the initial uptake coefficient, $\gamma_{0}$, was determined. After a certain time, when the IR bands increased at a stable speed, the steady state uptake coefficient, $\gamma_{s s}$, was determined. Three sets of experiments were performed: the first in which the $\mathrm{SO}_{2}$ concentration was varied and the $\mathrm{O}_{3}$ and water vapor concentrations were kept constant; the second in which the $\mathrm{O}_{3}$ concentration was varied and the $\mathrm{SO}_{2}$ and water vapor concentrations were kept constant; and the third in which $\mathrm{O}_{3}$ and $\mathrm{SO}_{2}$ concentrations were kept constant and water vapor concentration was varied.

The BET surface area has been previously determined to be $1.95\left(\mathrm{~m}^{2} \mathrm{~g}^{-1}\right)$ and the uptake coefficients calculated using this data are listed in Table 1 together with uptake coefficients calculated with the geometric surface area. The uptake 
coefficients obtained using the BET surface area as the reactive surface area should be considered as lower limits. In this experiment, the BET surface area is a factor of $5.5 \times 10^{3}$ times larger than the geometric surface area. This means that the dust particles must be non-porous. The initial uptake coefficient for $\mathrm{SO}_{2}$ is $7.7 \times 10^{-4}$ if the geometric surface area is used and $1.4 \times 10^{-7}$ if the BET surface area is applied; the steady state uptake coefficients for $\mathrm{SO}_{2}$ are $8.1 \times 10^{-5}$ and $1.5 \times 10^{-8}$, respectively.

There are several studies concerning the uptake of $\mathrm{SO}_{2}$ and $\mathrm{O}_{3}$ on different surfaces or materials, and most of them were deduced from experimental results using Knudsen Cell reactors and DRIFTS reactors. One such study investigated the uptake of $\mathrm{SO}_{2}$ and reported uptake coefficients in the order of $10^{-5}$ on China Loess (Usher et al., 2002), which is about two orders of magnitude higher than our result. A rough estimate of the equivalent uptake coefficient can be made from the deposition velocity using the expression $\gamma=4 v_{d} / v_{m}$, where the $v_{d}$ is the deposition velocity and $v_{m}$ is the molecular velocity (Dentener et al., 1996). The uptake coefficient is estimated to be $5 \times 10^{-5}$, which is also about two orders of magnitude higher than our result.

The uptake coefficients for $\mathrm{SO}_{2}$ in the presence of $\mathrm{O}_{3}$ was measured using the Knudsen and DRIFTS techniques. The corresponding data differ by several orders of magnitude (Table 2), possibly due to the different measurements principles. While the Knudsen Cell techique measures the rate of loss of the gaseous species during exposure, the DRIFTS method determines the formation rate of the products on the reactive surface.

The data from Table 2 can be used for a comparison of uptake coefficients obtained from different experimental studies. For the same kind of particles, the uptake coefficients can differ by about one order of magnitude depending on the type of measurement technique (Knudsen Cell and DRIFTS reactor). The difference due to the choice of the effective surface area (geometric or BET surface area) is much larger, about three orders of magnitude. This means that the value of the derived uptake coefficients depends much more on the measurement technique and the assumption of the size of the surface areas rather than on the different kinds of particle substrates. Ullerstam et al. (2003) assumed that the difference in uptake coefficient from different studies is more likely due to a difference between substances than caused by experimental artifacts. Our analysis, however, suggests that such differences are more likely caused by experimental artifacts and the way of measurement evaluation. This is a very important problem because uptake coefficient data are required to represent the reactivity of heterogeneous reactions in the atmosphere (Ravishankara, 1997; Molina et al., 1996; Schurath et al., 1998). More accurate measurements of the effective surface area of reactive particles are therefore needed to obtain realistic uptake coefficients.

Equation (1) shows that in the case of a first-order reaction, the uptake coefficient is independent of the reactant concen-
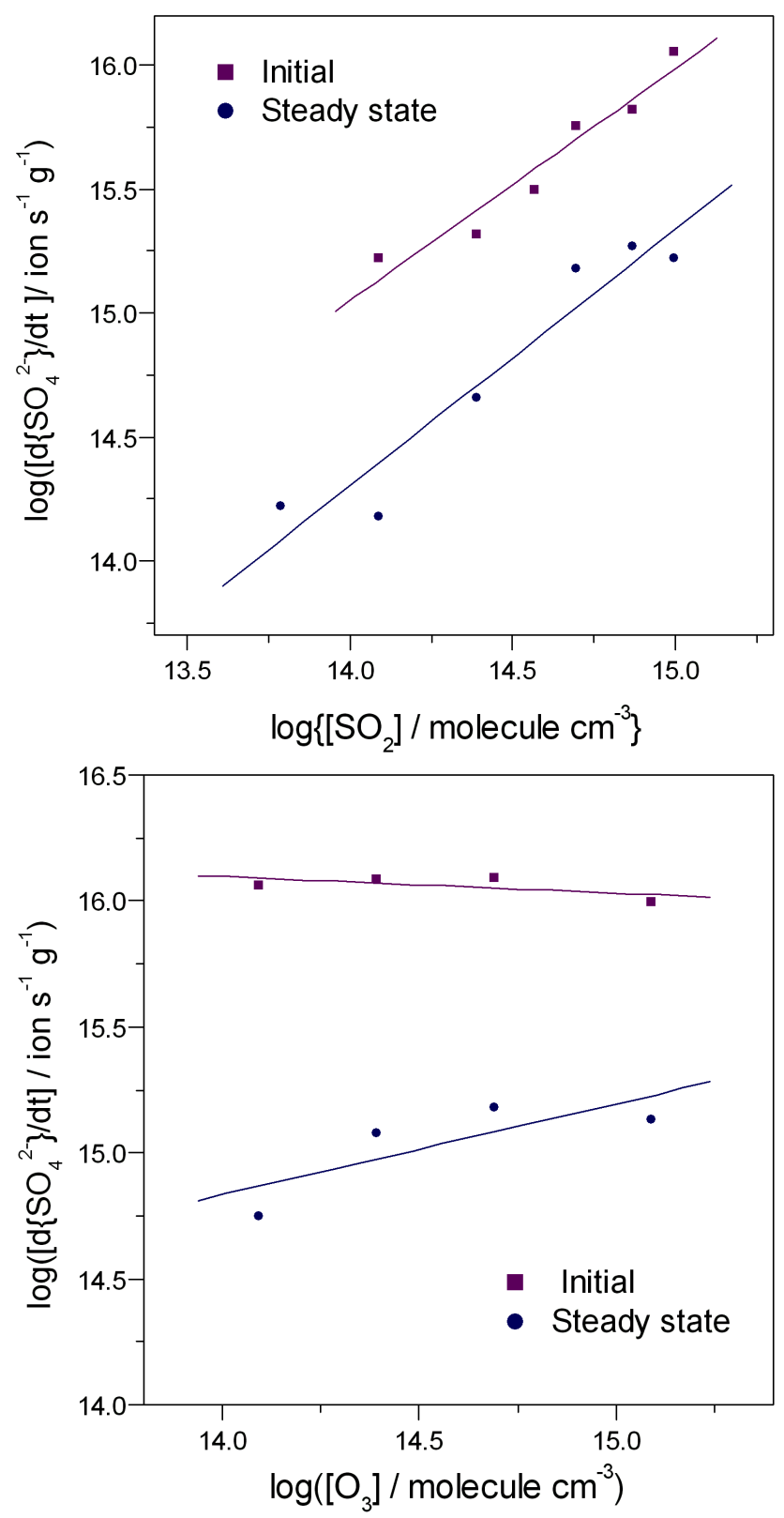

Fig. 8. Double-logarithmic plot of the rate of sulfate formation as a function of $\left[\mathrm{SO}_{2}\right]$ and $\left[\mathrm{O}_{3}\right]$ at initial time and steady state. The reaction order in $\mathrm{SO}_{2}$ was determined from a linear regression yielding $\mathrm{n}_{0}=0.94 \pm 0.06(\sigma), \mathrm{n}_{s s}=1.04 \pm 0.13(\sigma)$. For $\mathrm{O}_{3}$ corresponding values are $\mathrm{n}_{0}=0.06 \pm 0.26(\sigma), \mathrm{n}_{s s}=0.36 \pm 0.45(\sigma)$.

tration, while the reaction rate is proportional to the reactant concentration. In case of a zero-order reaction, the reaction rate is concentration-independent. A double-logarithmic plot of the initial and steady state formation rates of sulfate (Fig. 8a) on $\mathrm{CaCO}_{3}$ particles versus the concentration of $\mathrm{SO}_{2}$ gives a slope of $0.94 \pm 0.13(\sigma)$ and $1.04 \pm 0.16(\sigma)$, respectively, which represents the reaction order in $\mathrm{SO}_{2}$. The 
Table 2. Initial uptake coefficients determined for heterogeneous reaction of $\mathrm{SO}_{2}$ on different particulates using a BET surface.

\begin{tabular}{|c|c|c|c|c|}
\hline Reference & Gas & Reactor & Particulates & $\gamma_{0}$ \\
\hline Goodman et al. (2001) & $\mathrm{SO}_{2}$ & Knudsen Cell & $\begin{array}{c}\alpha-\mathrm{Al}_{2} \mathrm{O}_{3} \\
\mathrm{MgO}\end{array}$ & $\begin{array}{l}1 \times 10^{-4} \\
3 \times 10^{-4}\end{array}$ \\
\hline Usher et al. (2002) & $\mathrm{SO}_{2}$ & Knudsen Cell & $\begin{array}{c}\mathrm{CaCO}_{3} \\
\text { China Loess }\end{array}$ & $\begin{array}{l}1 \times 10^{-4} \\
3 \times 10^{-5}\end{array}$ \\
\hline Ullerstam et al. (2002) & $\mathrm{SO}_{2}$ & DRIFTS $\left(\mathrm{O}_{3}\right)^{\mathrm{a}}$ & Mineral dust & $5 \times 10^{-7}$ \\
\hline Ullerstam et al. (2003) & $\mathrm{SO}_{2}$ & Knudsen Cell & Mineral dust & $5 \times 10^{-6}$ \\
\hline Dentener et al. (1996) & $\mathrm{SO}_{2}$ & Dry deposition & Limestone & $5 \times 10^{-5}$ \\
\hline This work & $\mathrm{SO}_{2}$ & DRIFTS $\left(\mathrm{O}_{3}\right)$ & $\mathrm{CaCO}_{3}$ & $2 \times 10^{-7}$ \\
\hline
\end{tabular}

a An oxidant is needed for testing reactive uptake coefficient

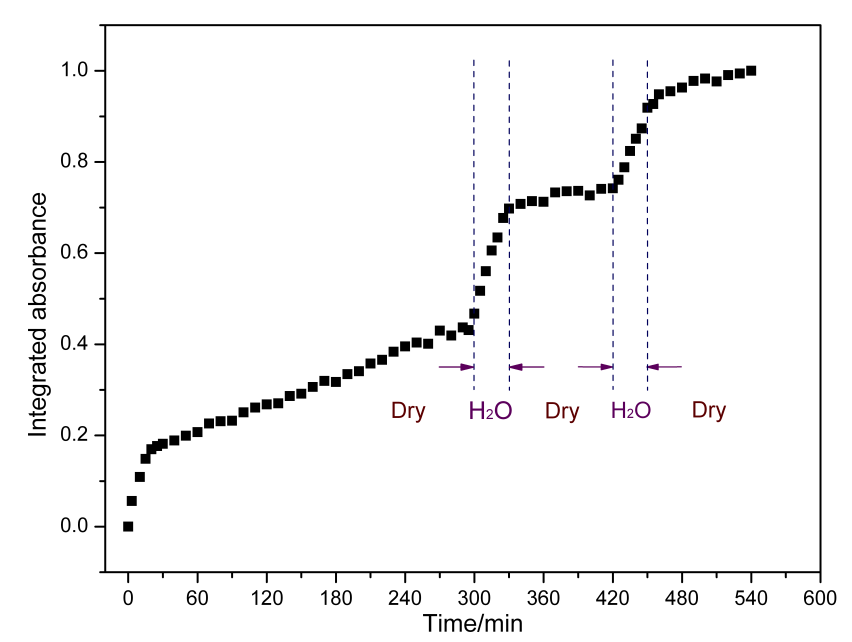

Fig. 9. Integrated absorbance of the sulfate band as a function of time in the reaction of $\mathrm{SO}_{2}$ and $\mathrm{O}_{3}$ on $\mathrm{CaCO}_{3}$. The vertical dashed lines indicate the time intervals when the sample was exposed to wet or dry air.

reaction orders, which are close to 1 , indicate that the uptake coefficients are independent of the $\mathrm{SO}_{2}$ concentration at both the initial stage and steady state stage.

An equivalent plot of the initial and steady state formation rate of sulfate vs. the $\mathrm{O}_{3}$ concentration (Fig. 8b) gives a slope of $-0.07 \pm 0.06(\sigma)$ and $0.36 \pm 0.20(\sigma)$, respectively. The reaction order is close to zero in the initial time stage and steady-state stage, which suggests that the sulfate formation rate is independent of the $\mathrm{O}_{3}$ concentration in the concentration range used in this study. Hence the uptake coefficient was inversely dependent on $\mathrm{O}_{3}$ concentration. The corresponding reactive uptake coefficients are shown in Table 1.

To study the effect of water in this reaction, the chemical role of gaseous water (relative humidity) and absorbed water must be considered. The experimental results have shown that the initial formation rate of sulfate is not affected by relative humidity (Table 1 ), but apparently the steady-state generation rate increases when the relative humidity is increased. As the sample pretreatments were the same in each experiment, and the adsorbed water on the particle surfaces must have been uniform for each experiment, the water taking part in the chemical reaction must be adsorbed. When the surface water is consumed within the reaction time, it must be replenished to keep the reaction going on. So during steady-state stage, the formation rate of sulfate is expected to depend on the relative humidity in the gas flow that controls the water adsorption rate on the particulate surface.

To simulate atmospheric conditions, another experiment was carried out to investigate the effect of water vapor on the sulfate formation. The $\mathrm{CaCO}_{3}$ sample was exposed to $\mathrm{SO}_{2}$ and $\mathrm{O}_{3}$ simultaneously for several hours, followed by exposure to $80 \% \mathrm{RH}$ of water vapor for $30 \mathrm{~min}$. During this period, the spectra showed a sulfate increase without any major changes on the shape of IR absorption bands. Even though there was no shift or any other changes in the sulfate bands, the total amount of formed sulfate increased by about two times as fast as that in the experiment without water vapor exposure (Fig. 9). During the steady-state stage, the integrated absorbance of the sulfate increased much faster when water vapor was present. Thus, our experimental results indicate that water vapor can regenerate the reactivity of $\mathrm{CaCO}_{3}$ particles and can enhance the capability of sulfate formation. The reason is probably that the product $\mathrm{CaSO}_{4}$, which is more hygroscopic than $\mathrm{CaCO}_{3}$, can combine with $\mathrm{H}_{2} \mathrm{O}$ to form $\mathrm{CaSO}_{4} \cdot \mathrm{nH}_{2} \mathrm{O}$. The molecular of $\mathrm{CaSO}_{4} \cdot \mathrm{nH}_{2} \mathrm{O}$ is bigger than $\mathrm{CaCO}_{3}$, thus the formation of $\mathrm{CaSO}_{4} \cdot \mathrm{nH}_{2} \mathrm{O}$ can modify the surface structure and exposes new reactive sites. These experimental observations, together with the fact that water vapor has a wet-dry cycle during day and night in the atmosphere, imply that the particles have a persistent capability for sulfate formation.

Ravishankara and Longfellow (1999) distinguished between two kinds of solids: dynamic solids, where the flux of the solid's constituent through the surface is much larger than that of the atmospheric reactant; and the second kind are rigid solids, where the surface is not refreshed via deposition 
or evaporation. The $\gamma_{s s}$ is lower than $\gamma_{0}$ by about one order of magnitude for the $\mathrm{SO}_{2}$ on $\mathrm{CaCO}_{3}$ surface, thus $\mathrm{CaCO}_{3}$ can be considered as a rigid solid.

\subsection{Mechanism}

Because the gas phase oxidation of $\mathrm{SO}_{2}$ by $\mathrm{O}_{3}$ can be neglected in the experiment, the main path of $\mathrm{SO}_{2}$ oxidation is a heterogeneous process on the particulate surface in this experiment. According to the results of the step-exposure experiments mentioned above, the following conclusions can be drawn:

1. $\mathrm{SO}_{2}$ can be absorbed on the surface of $\mathrm{CaCO}_{3}$ particles and form sulfite with adsorbed water.

2. Sulfite can be easily oxidized into sulfate by $\mathrm{O}_{3}$.

Therefore, we propose a reaction mechanism as follows: $\mathrm{SO}_{2}$ oxidation by $\mathrm{O}_{3}$ on the surface of $\mathrm{CaCO}_{3}$ particles proceeds via two major stages. At first, a reversible adsorption of $\mathrm{SO}_{2}$ to the surface occurs

$\mathrm{SO}_{2}(g) \overleftarrow{k_{-1}} \stackrel{k_{1}}{\longrightarrow} \mathrm{SO}_{2}($ ads $)$

With the existence of surface water, there should be equilibria among $\mathrm{SO}_{2}, \mathrm{HSO}_{3}^{-}$and $\mathrm{SO}_{3}^{2-}$. $\mathrm{CaCO}_{3}$ particles provide the basic sites where $\mathrm{H}^{+}$ions can be easily removed, and the equilibria shifted to the right and the reaction between the adsorbed $\mathrm{SO}_{2}$ and $\mathrm{H}_{2} \mathrm{O}$ can be expressed as

$\mathrm{SO}_{2}$ (ads) $+\mathrm{H}_{2} \mathrm{O}$ (ads) $\underset{\mathrm{CaCO}_{3}}{\stackrel{k_{2}}{\longrightarrow}} \mathrm{SO}_{3}^{2-}($ ads $)+2 \mathrm{H}^{+}($ads $)$

This reaction is relatively slow and determines the whole reaction rate. The $\mathrm{H}_{2} \mathrm{O}$ adsorbed on the surface takes part in the reactions.

The second stage is an irreversible reaction, in which the sulfite is oxidized to sulfate by $\mathrm{O}_{3}$. This reaction occurs very quickly. Since so far, no kinetic parameters are available for the the $\mathrm{S}(\mathrm{IV})$ oxidation involving $\mathrm{SO}_{2} \cdot \mathrm{H}_{2} \mathrm{O}, \mathrm{HSO}_{3}^{-}$or $\mathrm{SO}_{3}^{2-}$ ) on particle surfaces, the corresponding aqueous-phase kinetic parameters are used as an estimate. For the aqueous phase reaction: $\mathrm{S}(\mathrm{IV})+\mathrm{O}_{3} \longrightarrow \mathrm{S}(\mathrm{VI})+\mathrm{O}_{2}$, the expression for the rate of the reaction of $\mathrm{S}(\mathrm{IV})$ with dissolved ozone is: $\mathrm{R}_{0}=-\frac{d[\mathrm{~S}(\mathrm{IV})]}{d t}=\left(k_{0}\left[\mathrm{SO}_{2} \cdot \mathrm{H}_{2} \mathrm{O}\right]+k_{1}\left[\mathrm{HSO}_{3}^{-}\right]+k_{2}\left[\mathrm{SO}_{3}^{2-}\right]\right)$ $\left[\mathrm{O}_{3}\right]$, with $\mathrm{k}_{0}=2.4 \pm 1.1 \times 10^{4} \mathrm{M}^{-1} \mathrm{~s}^{-1}$,

$\mathrm{k}_{1}=3.7 \pm 0.7 \times 10^{5} \mathrm{M}^{-1} \mathrm{~s}^{-1}, \quad \mathrm{k}_{2}=1.5 \pm 0.6 \times 10^{9} \mathrm{M}^{-1} \mathrm{~s}^{-1}$ (Hoffmann, 1985). From the rate constants above, we can deduce that the reaction between $\mathrm{SO}_{3}^{2-}$ and $\mathrm{O}_{3}$ is the most rapid. The surface reaction can be expressed as

$\mathrm{SO}_{3}^{2-}$ (ads) $+\mathrm{O}_{3} \stackrel{k_{3}}{\longrightarrow} \mathrm{SO}_{4}^{2-}($ ads $)+\mathrm{O}_{2}(g)$

Thus, the reaction rate of sulfate formation can be described by the general equation:

$r=\frac{d\left\{\mathrm{SO}_{4}^{2-}\right\}}{d t}=k_{3}\left\{\mathrm{SO}_{3}^{2-}\right\}\left[\mathrm{O}_{3}\right]$

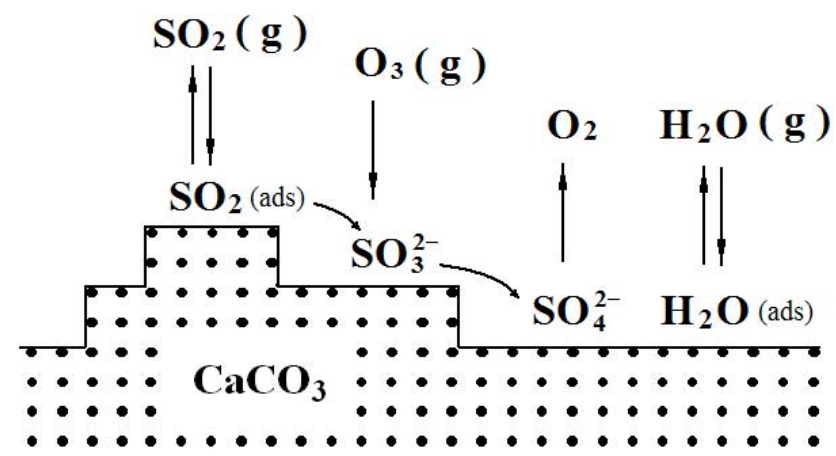

Fig. 10. Schematic diagram of the mechanism of $\mathrm{SO}_{2}$ oxidation by $\mathrm{O}_{3}$ on $\mathrm{CaCO}_{3}$ surface. Gas-phase $\mathrm{SO}_{2}$ can be adsorbed on the surface. At the same time, water vapor can be reversibly adsorbed on surface. Under the cooperation of adsorbed water and the basicity given by $\mathrm{CaCO}_{3}$, adsorbed $\mathrm{SO}_{2}$ is transformed into sulfite, and then the sulfite is rapidly oxidized into sulfate by $\mathrm{O}_{3}$.

When $\mathrm{CaCO}_{3}$ was exposed to $\mathrm{SO}_{2}$ and $\mathrm{O}_{3}$ simultaneously, no adsorbed $\mathrm{SO}_{2}$ and sulfite was observed. This phenomenon means that the $\mathrm{SO}_{2}$ adsorbed on the surface is quickly transformed into sulfite, then the sulfite is immediately oxidized into sulfate. According to the steady-state approximation, the net rate of change of the intermediates may be set equal to zero. For the intermediates in the $\mathrm{SO}_{2}$ surface oxidation, i.e. surface $\mathrm{SO}_{2}$ and $\mathrm{SO}_{3}^{2-}$, the generation rate is then equal to their consumption rate:

$\frac{d\left\{\mathrm{SO}_{2}\right\}}{d t}=k_{1}\left[\mathrm{SO}_{2}\right]-k_{-1}\left\{\mathrm{SO}_{2}\right\}-k_{2}\left\{\mathrm{SO}_{2}\right\}=0$

$\frac{d\left\{\mathrm{SO}_{3}^{2-}\right\}}{d t}=k_{2}\left\{\mathrm{SO}_{2}\right\}-k_{3}\left\{\mathrm{SO}_{3}^{2-}\right\}\left[\mathrm{O}_{3}\right]=0$

Thus:

$r=\frac{d\left\{\mathrm{SO}_{4}^{2-}\right\}}{d t}=\frac{k_{1} k_{2}}{k_{-1}+k_{2}}\left[\mathrm{SO}_{2}\right]=k\left[\mathrm{SO}_{2}\right]$

where: $k=\frac{k_{1} k_{2}}{k_{-1}+k_{2}}$.

From Eq. (10), we can see that the reaction is first order for $\mathrm{SO}_{2}$ and zero order for $\mathrm{O}_{3}$. Therefore, the reaction order deduced from the proposed mechanism is well consistent with the experimental results shown in Fig. 9. The mechanism we propose is illustrated in Fig. 10. It should be pointed out that the above mechanism is deduced in confined experimental conditions. It can not be used under all conditions without further proof.

\subsection{Atmospheric implication}

The formation of surface sulfate changes the physical properties of the mineral particles, thus, it will have an important impact on atmospheric chemistry and climate. Surface 


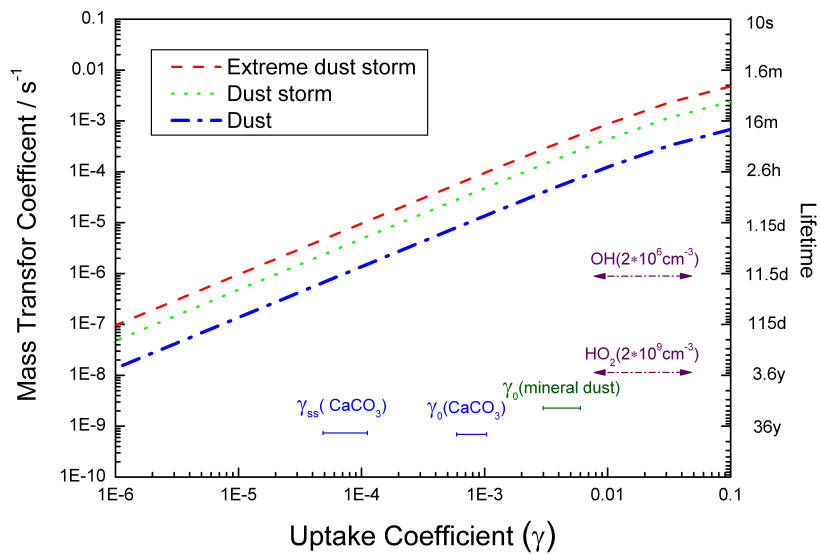

Fig. 11. Calculated mass transfer coefficients under different dust scenarios as a function of the heterogeneous uptake $\gamma$ (measured values of $\gamma$ are indicated by the line). $\mathrm{SO}_{2}$ oxidation rates by $\mathrm{OH}$ in the gas phase $\left([\mathrm{OH}]=1 \times 10^{6}\right.$ molecule $\left.\mathrm{cm}^{-3}\right)$. Data used for the calculations: diffusivity (D), $0.148 \mathrm{~cm}^{2} \mathrm{~s}^{-1}$; density, $2.0 \mathrm{~g} \mathrm{~cm}^{-3}$; lognormal distribution for dust: $\mathrm{n}($ average $)=7.98, \mathrm{n}($ strom $)=28.0$, $\mathrm{n}($ extreme strom) $=56.0 ; \mathrm{r}, 0.88 \mu \mathrm{m} ; \log (\sigma), 0.23$ (Li et al., 2001; Zhang and Carmichael, 1999). The results of Ullerstam et al. (2002) are shown for comparison. This diagram shows that under certain conditions loss rates of $\mathrm{SO}_{2}$ through heterogeneous uptake are comparable to other loss rate mechanisms.

sulfate will adsorb more water than the unprocessed original particles. The water on the surface will permit more $\mathrm{SO}_{2}$ into the aqueous layer. The radiation properties of mineral dust particles coated with sulfate are assumed to be unaffected. If a significant fraction of sulfate is formed on mineral dusts rather than by gas phase oxidation, this could influence the estimates of the aerosol radiation forcing and the sulfate cooling effect could be overestimated (Dentener et al., 1996). In order to better understand the relevance of the heterogeneous $\mathrm{SO}_{2}$ oxidation, it is necessary to compare its reaction rate with the gas phase mechanism. Li and coworkers introduced a pseudo-first order mass transfer constant expressed by the following equations to describe rates of heterogeneous reactions (Li et al., 2001; Usher et al., 2002; Fuchs and Sutugin, 1971).

$k_{j}=\int_{r_{2}}^{r_{1}} 4 \pi r^{2} F(r) \frac{d n}{d r} d r$

$F(r)=\frac{D_{j} / r}{1+f\left(K_{n}, \gamma\right) K_{n}}$

$f\left(K_{n}, \gamma\right)=\frac{1.333+0.71 K_{n}^{-1}}{1+K_{n}^{-1}}+\frac{4(1-\gamma)}{3 \gamma}$

Here $k_{j}$ is the overall mass transfer coefficient of reactant $\mathrm{j}\left(\mathrm{cm}^{3} \mathrm{~s}^{-1}\right) ; K_{n}$ is the dimensionless Knudsen number $\left(K_{n}=\lambda / \mathrm{r}\right) ; \lambda$ is the effective mean free path of gas molecules; $\mathrm{r}$ is the particle radius; $\mathrm{F}(\mathrm{r})$ is the flux of the reactant gas to the surface of a particle with radius $\mathrm{r}$ (molecules $\mathrm{cm} \mathrm{s}^{-1}$ ); $\mathrm{dn} / \mathrm{dr}$ is the number-size distribution of particles; and $\gamma$ is uptake coefficient, which was calculated using the geometric surface area as an effective sample surface.

Since the total surface area which is available for the reaction plays a role in heterogeneous chemistry, the mass transfer coefficient $\left(\mathrm{k}_{j}\right)$ was calculated from the above expressions as a function of the uptake coefficient using a series of lognormal distributions for the aerosol number-size distribution expressed in the following manner:

$$
\frac{d n(r)}{d(\log r)}=\sum_{i=1}^{3} \frac{n_{i}}{\log \sigma_{i} \sqrt{2 \pi}} \exp \left[\frac{-\left(\log r / R_{i}\right)^{2}}{2\left(\log \sigma_{i}\right)^{2}}\right]
$$

where $\mathrm{r}$ is the particle radius $(\mu \mathrm{m}), \mathrm{n}(\mathrm{r})$ is the cumulative particle number distribution for particles larger than $r$ $\left(\mathrm{cm}^{-3}\right), \mathrm{R}$ is the mean particle radius $(\mu \mathrm{m}), \mathrm{n}$ is the integral of the lognormal function, and $\log \sigma$ is a measure of particle polydispersity. These distributions represent dust, dust storm and extreme dust storm conditions. The corresponding lifetime of gases is calculated as a function of $\gamma$ as presented in Fig. 11. The lifetime of $\mathrm{SO}_{2}$ calculated from the reaction with $\mathrm{OH}$ and $\mathrm{HO}_{2}$ radicals in the gas phase is equal to 13 days $\left(9 \times 10^{-13} \mathrm{~cm}^{3}\right.$ molecule ${ }^{-1} \mathrm{~s}^{-1}$ for an $\mathrm{OH}$ reaction rate constant and 12-h daytime average of $2 \times 10^{6}$ molecule $\mathrm{cm}^{-3}$ for $\mathrm{OH}$ concentration) and 3.2 years $\left(1 \times 10^{-18} \mathrm{~cm}^{3}\right.$ molecule $\mathrm{s}^{-1} \mathrm{~s}^{-1}$ for $\mathrm{HO}_{2}$ reaction rate constant and 12-h daytime average of $2 \times 10^{9}$ molecule $\mathrm{cm}^{-3}$ for $\mathrm{HO}_{2}$ concentration). This is listed at the right of the plot (Finlayson-Pitts, 1999). The range of $\gamma$ for $\mathrm{SO}_{2}$ was shown at the bottom of the plot. There is a specific rate constant and a specific lifetime associated with a given $\gamma$. At any aerosol size distribution, the relative importance of the heterogeneous $\mathrm{SO}_{2}$ loss can be evaluated against the gas-phase loss. According to our results, the life time of $\mathrm{SO}_{2}$ reacting on $\mathrm{CaCO}_{3}$ surfaces is $20-30 \mathrm{~h}$ in dust conditions, $5-10 \mathrm{~h}$ for dust storms and $3-5 \mathrm{~h}$ for extreme dust storm conditions. This calculation suggests that under dust conditions, the heterogeneous loss of $\mathrm{SO}_{2}$ has a similar magnitude as the gasphase loss process, so the heterogeneous reactions can be an important sink for $\mathrm{SO}_{2}$. Ullerstam et al. (2002) tested the reactive uptake coefficient of $\mathrm{SO}_{2}$ on the surface of Saharan dust and found it to be $4 \pm 1 \times 10^{-3}$, which is larger than our results $\left(8 \pm 2 \times 10^{-4}\right)$. According to the results of Ullerstam, the life time of $\mathrm{SO}_{2}$ for reactions on mineral dust surfaces is $3-6 \mathrm{~h}$ for dust, $1-2 \mathrm{~h}$ for dust storm and $0.5-1 \mathrm{~h}$ for extreme dust storm conditions, thus these lifetimes are shorter than our results. This suggests that the heterogeneous reaction of $\mathrm{SO}_{2}$ will have an influence on the formation rate of sulfate only under dust conditions. The actual average lifetime of $\mathrm{SO}_{2}$ is around 5 days due to cloud processing (Boniface et al., 2000; Jayne et al., 1990). In addition, the concentrations of reactants can also affect the uptake coefficients, for the uptake coefficients might be significantly higher at lower 
concentration. The interplay between relative concentrations at the surface of the dust particle will ultimately determine the removal rate of $\mathrm{O}_{3}$ and the formation rate of sulfate.

However, large uncertainties remain due to the lack of detailed information about the size distribution and surface properties. The result of a recent field study by Umann et al. (2005) showed that dust had no negative impact on $\mathrm{SO}_{2}$ concentrations. The reason that the dust had no (negative) impact on $\mathrm{SO}_{2}$ concentrations was because the dust composition possibly has a great influence on uptake of $\mathrm{SO}_{2}$, but the paper did not indicate which component was important.

\section{Conclusions}

The kinetics and the mechanism of $\mathrm{SO}_{2}$ oxidation on $\mathrm{CaCO}_{3}$ particles were studied, using the DRIFTS technique. The initial and steady-state reactive uptake-coefficients were determined. The initial reactive uptake-coefficient was determined to be $(7.7 \pm 1.6) \times 10^{-4}$ when the reactive surface area was assumed to the geometric surface area, or $(1.4 \pm 0.3) \times 10^{-7}$ when a BET surface area was assumed. The steady-state uptake coefficient is lower by one order of magnitude than the initial coefficient.

The reaction mechanism was studied by step-exposure experiments. A two-stage mechanism is proposed, involving the absorption of $\mathrm{SO}_{2}$ on the $\mathrm{CaCO}_{3}$ surface to form $\mathrm{SO}_{3}^{2-}$ in the presence of water, followed by $\mathrm{O}_{3}$ oxidation to form sulfate. The adsorption of $\mathrm{SO}_{2}$ is the rate-determining step. $\mathrm{O}_{3}$ and water take part in the reaction in their gaseous and adsorption forms, respectively. The reaction was determined to be first order in $\mathrm{SO}_{2}$ and zero order in $\mathrm{O}_{3}$ within the experimental concentration range. The reaction order deduced from the proposed mechanism is in good agreement with the experimental results.

Using the $\mathrm{SO}_{2}$ uptake coefficient, together with the number concentration distribution of atmospheric aerosols under typical conditions, a box model calculation has shown that the atmospheric $\mathrm{SO}_{2}$ loss by heterogeneous oxidation is comparable to loss by the gas phase oxidation under dust conditions. Thus, the heterogeneous reaction may be an important path for sulfate formation in the atmosphere under such conditions.

Acknowledgements. This work was supported by the Project of Development Plan of the State Key Fundamental Research (Grant No. 2002CB410801, 2002CB410802) and the National Natural Science Foundation of China (Grant No. 20077001, 20107001).

Edited by: M. Ammann

\section{References}

Alebić-Juretić, A., Cvitaš, T., and Klasinc, L.: Kinetics of heterogeneous ozone reactions, Chemosphere, 41, 667-670, 2000.

Al-Hosney, H. A. and Grassian, V. H.: Carbonic acid: An important intermediate in the surface chemistry of calcium carbonate, J. Amer. Chem. Soc., 126, 8068-8069, 2004.

Boniface, J., Shi, Q., Li, Y., Cheung, J. L., Rattigan, O. V., Davidovits, P., Worsnop, D. R., Jayne, J. T., and Kolb, C. E.: Uptake of gas-phase $\mathrm{SO}_{2}, \mathrm{H}_{2} \mathrm{~S}$, and $\mathrm{CO}_{2}$ by aqueous solutions, J. Phys. Chem. A, 104, 7502-7512, 2000.

Börensen, C., Kirchner, U., Scheer, V., Vogt, R., and Zellner, R.: Mechanism and Kinetics of the Reactions of $\mathrm{NO}_{2}$ or $\mathrm{HNO}_{3}$ with Alumina as a Mineral Dust Model Compound, J. Phys. Chem. A., 104, 5036-5045, 2000.

Capaldo, K., Corbett, J. J., Kasibhatla, P., Fischbeck, P., and Pandis, S. N.: Effects on ship emissions on sulphur cycling and radiative climate forcing over the ocean, Nature, 400, 743-746, 1999.

Carmichael, G. R., Zhang, Y., Chen, L. L., Hong, M. S., and Ueda, H.: Seasonal variation of aerosol composition at Cheju Island, Korea, Atmos. Environ., 30, 2407-2416, 1996.

Chandler, A. S., Choularton, T. W., Dollard, G. J., Eggleton, A. E. J., Gay, M. J., Hill, T. A., Jones, B. M. R., Tyler, B. J., Bandy, B. J., and Penkett, S. A.: Measurments of $\mathrm{H}_{2} \mathrm{O}_{2}$ and $\mathrm{SO}_{2}$ in clouds and estimates of their reaction rate, Nature, 336, 562-565, 1988.

Charlson, R. J., Langner, J., and Rodhe, H.: Sulfate aerosol and climate, Nature, 348, 22, 1990.

Davis, B. L. and Guo, J.: Airborne particulate study in five cities of China, Atmos. Environ., 34, 2703-2711, 2000.

Dentener, F. J., Carmichael, G. R., Zhang, Y., Lelieveld, J., and Crutzen, P. J.: Role of mineral aerosol as a reactive surface in the global troposphere, J. Geophys. Res.-Atmos., 101, 22 869$22889,1996$.

Faust, B. C., Hoffman, M. R., and Bahnemann, D. W.: Photocatalytic oxidation of sulfur dioxide in aqueous suspensions of airon oxide $\left(\mathrm{Fe}_{2} \mathrm{O}_{3}\right)$, J. Phys. Chem., 93, 6371-6381, 1989.

Finlayson-Pitts, B. J.: Chemistry of the Upper and Lower Atmosphere - Theory, Experiments, and Applications, Acdemic Press, New York, 2000.

Fuchs, N. A. and Sutugin, A. G.: Highly dispersed aerosol, in: Topics in current aerosol research (Part 2), edited by: Hidy, G. M. and Brock, J. R., Pergamon Press, New York, 1-60, 1971.

Goodman, A. L., Li, P., Usher, C. R., and Grassian, V. H.: Heterogeneous uptake of sulfur dioxide on aluminum and magnesium oxide particles, J. Phys. Chem. A., 105, 6109-6120, 2001.

Goudie, A. S. and Middleton, N. J.: Saharan dust storms: nature and consequences, Earth Sci. Rev., 56, 179-204, 2001.

Hanisch, F. and Crowley, J. N.: The heterogeneous reactivity of gaseous nitric acid on authentic mineral dust samples, and on individual mineral and clay mineral components, Phys. Chem. Chem. Phys., 3, 2474-2482, 2001.

Hoffmann, M. R. and Calvert, J. G.: Chemical transformation modules for eulerian acid deposition models, Volume 2, The Aqueous-phase Chemistry, EPA/600/3-85/017, U.S. Environment Protection Agency, Research Triangle Park, NC, 1985.

Hoppel, W. A. and Caffrey, P. F.: Oxidation of S(IV) in sea-salt aerosol at high $\mathrm{pH}$ : Ozone versus aerobic reaction, J. Geophys. Res.-Atmos., 110, D23202, doi:10.1029/2005JD006239, 2005.

Jacob, D. J.: Heterogeneous chemistry and tropospheric ozone, Atmos. Environ., 34, 2131-2159, 2000. 
Jayne, J. T., Davidovits, P., Worsnop, D. R., Zahniser, M. S., and Kolb, C. E.: Uptake of sulfur dioxide by aqueous surfaces as a function of $\mathrm{pH}$ : The effect of chemical reaction at the interface, J. Phys. Chem., 94, 6041-6048, 1990.

Keene, W. C., Sander, R., Pszenny, A. A. P., Vogt, R., Crutzen, P. J., and Galloway, J. N.: Aerosol pH in the marine boundary layer: A review and model evaluation, J. Aerosol Sci., 29, 339-356, 1998.

Krischke, U., Staubes, R., Brauers, T., Gautrois, M., Burkert, J., Stobener, D., and Jaeschke, W.: Removal of $\mathrm{SO}_{2}$ from the marine boundary layer over the Atlantic Ocean: A case study on the kinetics of the heterogeneous S(IV) oxidation on marine aerosols, J. Geophys. Res.-Atmos., 105, 14 413-14 422, 2000.

Li, P., Perreau, K. A., Covington, E., Song, C. H., Carmichael, G. R., and Grassian, V. H.: Heterogeneous reactions of volatile organic compounds on oxide particles of the most abundant crustal elements: Surface reactions of acetaldehyde, acetone, and propionaldehyde on $\mathrm{SiO}_{2}, \mathrm{Al}_{2} \mathrm{O}_{3}, \mathrm{Fe}_{2} \mathrm{O}_{3}, \mathrm{TiO}_{2}$, and $\mathrm{CaO}$, J. Geophys. Res.-Atmos., 106, 5517-5529, 2001.

Lu, S. and Shao, L.: Mineral compositions of individual particulates in PM10 over Beijing, Acta petro et mineral (in Chinese with English abstract), 22, 421-424, 2003.

Mamane, Y., Ganor, E., and Donagi, A. E.: Aerosol composition of urban and desert origin in the eastern Mediterranean, I. Individual particle analysis, Water Air Soil Pollut., 14, 29-43, 1980.

Martin, L. R. and Good, T. W.: Catalyzed oxidation of sulfur dioxide in solution: The iron-manganese synergism, Atmos. Environ. A, 25A, 2395-2399, 1991.

Molina, M. J., Molina, L.T., and Golden, D. M.: Environmental Chemistry (Gas and Gas-Solid Interactions): The role of Physical Chemistry, J. Phys. Chem., 100, 12 888-12 896, 1996.

Nakamoto, K.: Infrared and Raman Spectra of Inorganic and Coordination Compounds, Wiley, New York, 1997.

Nishikawa, M., Kanamori, S., Kanamori, N., and Mizoguchi, T.: Kosa Aerosol as Eolian Carrier of Anthropogenic Material, Sci. Total Environ., 107, 13-27, 1991.

Phadnis, M. J. and Carmichael, G. R.: Numerical investigation of the influence of mineral dust on the tropospheric chemistry of East Asia, J. Atmos. Chem., 36, 285-323, 2000.

Putnis, A.: Introduction to mineral sciences, Cambridge University Press, 1992.

Rattigan, O. V., Boniface, J., Swartz, E., Davidovits, P., Jayne, J. T., Kolb, C. E., and Worsnop, D. R.: Uptake of gas-phase $\mathrm{SO}_{2}$ in aqueous sulfuric acid: oxidation by $\mathrm{H}_{2} \mathrm{O}_{2}, \mathrm{O}_{3}$ and $\mathrm{HONO}, \mathrm{J}$. Geophys. Res.-Atmos., 105, 29 065-29 078, 2000.

Ravishankara, A. R. and Longfellow, C. A.: Reactions on tropospheric condensed matter, Phys. Chem. Chem. Phys., 1, 54335441, 1999.

Ravishankara, A. R.: Heterogeneous and multiphase chemistry in the troposphere, Science, 276, 1058-1065, 1997.

Robbins, L. L. and Fabry, V. J.: Carbon Dioxide Chemistry: Environmental Issues, The Royal Society of Chemistry, Cambridge, 1994.

Savoie, D. L., Prospero, J. M., and Saltzman, E. S.: Non-sea-salt sulfate and nitrate in trade wind aerosols at Barbados: evidence for long-range transport, J. Geophys. Res.-Atmos., 99, 50695080, 1989.

Schurath, U. and Naumann, K. H.: Heterogeneous process involving atmospheric particulate matter, Pure Appl. Chem., 70, 13531361, 1998.
Seinfeld, J. H. and Pandis, S. N.: Atmospheric Chemistry and Physics: From Air Pollution to Climate Change, John Wiley \& Sons, 1998.

Siefert, R. L., Webb, S. M., and Hoffman, M. R.: Determination of photochemically available iron in ambient aerosols, J. Geophys. Res.-Atmos., 101, 14 441-14 450, 1996.

Song, C. H. and Carmichael, G. R.: Partitioning of $\mathrm{HNO}_{3}$ modulated by alkaline aerosol particles, J. Atmos. Chem., 40, 1-22, 2001.

Sundquist, E. T.: Carbon Cycle and Atmospheric $\mathrm{CO}_{2}$ : Natural Variations Archean to Present, Geophysical Monograph, 32, American Geophysical Union, 1985.

Ullerstam, M., Johnson, M. S., Vogt, R., and Ljungström, E.: DRIFTS and Knudsen cell study of the heterogeneous reactivity of $\mathrm{SO}_{2}$ and $\mathrm{NO}_{2}$ on mineral dust, Atmos. Chem. Phys., 3, $2043-$ 2051, 2003, http://www.atmos-chem-phys.net/3/2043/2003/.

Ullerstam, M., Vogt, R., Langer, S., and Ljungström, E.: The kinetics and mechanism of $\mathrm{SO}_{2}$ oxidation by $\mathrm{O}_{3}$ on mineral dust, Phys. Chem. Chem. Phys., 4, 4694-4699, 2002.

Umann, B., Arnold, F., Schaal, C., Hanke, M., Uecker, J., Aufmhoff, H., Balkanski, Y., and Van Dingenen, R.: Interaction of mineral dust with gas phase nitric acid and sulfur dioxide during the MINATROC II field campaign: First estimate of the uptake coefficient $\gamma \mathrm{HNO}_{3}$ from atmospheric data, J. Geophys. Res., 110, D22306, doi:10.1029/2005JD005906, 2005.

Usher, C. R., Al-Hosney, H., Carlos-Cuellar, S., and Grassian, V. H.: A laboratory study of the heterogeneous uptake and oxidation of sulfur dioxide on mineral dust particles, J. Geophys. Res.Atmos., 107, 4713-4722, 2002.

Usher, C. R., Michel, A. E., and Grassian, V. H.: Reactions on mineral dust, Chem. Rev., 103, 4883-4939, 2003.

Vogt, R. and Finlayson-Pitts, B. J.: A diffuse reflectance infrared fourier transform spectroscopic (DRIFTS) study of the surface reaction of $\mathrm{NaCl}$ with gaseous $\mathrm{NO}_{2}$ and $\mathrm{HNO}_{3}$, J. Phys. Chem., 98, 3747-3755, 1994.

Xiao, H., Carmichael, G. R., Durchenwald, J., Thornton, D., and Bandy, A.: Long-range transport of SOx and dust in East Asia during the PEM B Experiment, J. Geophys. Res.-Atmos., 102, 28 589-28 612, 1997.

Zhang, D. Z., Shi, G. Y., Iwasaka, Y., and Hu, M.: Mixture of sulfate and nitrate in coastal atmospheric aerosols: individual particle studies in Qingdao (36 degrees $04^{\prime}$ N, 120 degrees $21^{\prime} \mathrm{E}$ ), China, Atmos. Environ., 34, 2669-2679, 2000.

Zhang, Y. and Carmichael, G. R.: The role of mineral aerosol in tropospheric chemistry in East Asia - A model study, J. Appl. Meteorol., 38, 353-366, 1999.

Zhu, T., Ding, J., Xu, B., Hu, M., Li, Y., and Li, L.: Study on Inorganic Components in Particles of Dust Storm with Diffuse Reflectance Infrared Fourier Transform Spectroscopic (DRIFTS), (in Chinese with English abstract), J. Fudan Univ. (Nat. Sci.), 42, 257-261, 2003.

Zhuang, H. C., Chan, C. K., Fang, M., and Wexler, A. S.: Formation of nitrate and non-sea-salt sulfate on coarse particles, Atmos. Environ., 33, 4223-4233, 1999.

Zuo, Y. and Hoigne, J.: Evidence for photochemical formation of $\mathrm{H}_{2} \mathrm{O}_{2}$ and oxidation of $\mathrm{SO}_{2}$ in authentic fog water, Science, 260, 71-73, 1993. 